\title{
Human development index, maternal mortality rate and under 5 years mortality rate in West and South Asian countries, 1980-2010: an ecological study
}

Yousef Alimohamadi, ${ }^{1}$ Farzad Khodamoradi, ${ }^{1}$ Malihe Khoramdad, ${ }^{2}$ Mohammad Shahbaz ${ }^{3}$ and Firooz Esmaeilzadeh ${ }^{4}$

${ }^{1}$ Department of Epidemiology and Biostatistics, School of Public Health, Tehran University of Medical Sciences, Tehran, Islamic Republic of Iran. ${ }^{2}$ Faculty of health, Kermanshah University of Medical Sciences, Kermanshah, Islamic Republic of Iran. ${ }^{3}$ Department of epidemiology, School of Public Health, Shahid Beheshti University of Medical Sciences, Tehran, Islamic Republic of Iran. ${ }^{4}$ School of Nursing and Midwifery, Maragheh University of Medical Sciences, Maragheh, Islamic Republic of Iran. (Correspondence to: Firooz Esmaeilzadeh: firooz.esmaeilzadeh@gmail.com).

\begin{abstract}
Background: Human Development Index (HDI), maternal mortality rate (MMR) and children aged under 5 years mortality rate ( $\left.\mathrm{U}_{5} \mathrm{MR}\right)$ are fundamental issues, especially in low- and middle-income countries.

Aims: The aim of this study was to evaluate the changes in HDI, MMR and U5MR from 1980 to 2010 in certain West Asian countries as well as the relationship between these indexes.
\end{abstract}

Methods: In this ecological study, HDI, MMR and U5MR information from studied countries during 1980 to 2010 was extracted from the gap minder site and then analysed using descriptive and analytical methods, including Spearman correlation.

Results: The lowest and highest rates of HDI and MMR in 2010 were seen in the United Arab Emirates and Pakistan (HDI: 0.49, 0.81; MMR: 7.14, 335.45 respectively). HDI is rising in all countries studied, with the highest increase in the Islamic Republic of Iran (0.21). MMR and U5MR saw a decline over the years, with the greatest decrease seen in India, and the lowest and highest child mortality rate in 2010 found in Bahrain and Pakistan (8.3, 91.8 respectively). However, there was a negative relationship between HDI and MMR $(r=-0.7, P<0.001)$.

Conclusions: HDI increased during 1980-2010. The highest rate of HDI decrease was observed in the Islamic Republic of Iran, and the greatest reduction of MMR was seen in India. Also, the highest decrease in U5MR was related to India as well, while MMR and U5MR rate decreased. Hence, improving HDI might have a definite impact on decreasing MMR and U5MR, especially in low- and middle-income countries.

Keywords: maternal mortality, child mortality, Human Development Index, Asia

Citation: Alimohamadi Y; Khodamoradi F; Khoramdad M; Shahbaz M; Esmaeilzadeh F. Human development index, maternal mortality rate and under 5 years mortality rate in West and South Asian countries, 1980-2010: an ecological study. East Mediterr Health J. 2019;25(3):189-196 https://doi. $\operatorname{org} / 10.26719 /$ emhj.18.029

Received: 12/09/16; accepted: 01/10/17

Copyright $@$ World Health Organization (WHO) 2019. Some rights reserved. This work is available under the CC BY-NC-SA 3.0 IGO license (https:// creativecommons.org/licenses/by-nc-sa/3.0/igo).

\section{Introduction}

Maternal mortality as well as deaths during pregnancy, childbirth or within 42 days after delivery remain major challenges for world health systems (1). Maternal mortality rate (MMR) is a sensitive indicator of health conditions and socio-economic development of a society, and forms Goal 5 of the Millennium Development Goals (MDG 5) to reduce MMR by three quarters from 1990 to $2015(1,2)$. The global ratio of maternal mortality declined to an estimated 216 deaths per 100000 live births during 1990-2015, less than MDG 5, and far from the target Sustainable Development Goal (SDG) of a reduction to 70 maternal deaths per 100000 live births by 2030 (3).

Since 1980, the world health community has taken measures to reduce maternal mortality through a series of initiative actions that began in 1987 with the mothers' safety movement (4). Maternal mortality in the world decreased by more than $40 \%$ during 1990-2015, from
532000 to 303000 deaths per year (5). In addition to maternal mortality, the mortality of children under 5 years of age (U5MR) has been considered an important indicator of health status and national prosperity in social and biomedical research, and forms the Goal 5 of the Millennium Development Goals (MDG 4) to reduce U5MR rate by two thirds during 1990-2015 $(6,7)$. From 1990 to 2015, the global rate of U5MR declined by more than half and reached 43 per 1000 live births. This was less than MDG 4 and far from the target SDG to end preventable deaths of children under 5 years by $2030(3,8)$.

In 2015, it was estimated that 5.9 million children aged under 5 years died (3). Child mortality rate has been widely used as an indicator of equality and human development (9). In 1990, the United Nations Development Programme (UNDP) introduced the Human Development Index (HDI) with the main aim of creating a more comprehensive measure of human development programmes $(10,11)$. The index has three aspects: longevity, knowledge, 
and life standards. These three aspects are respectively measured by life expectancy at birth, a combination of adults' literacy and enrollment rate, and Gross Domestic Product (GDP) per capita $(12,13)$. The HDI value is ranged zero to one $(14,15)$. Regarding HDI, countries are divided into three groups: countries with low (HDI $<0.500$ ), average (HDI $=0.500-0.799)$ and high $(\mathrm{HDI} \geq 0.800)$ development status (13). Given the importance of having knowledge concerning maternal and child mortalities in policy-making and planning and also the potential role of development indexes in maternal and child mortalities, the aim of this study was to evaluate the relationship between maternal and child mortalities and HDI in certain West Asian countries.

\section{Methods}

\section{Data and variables}

The variables in the present study included MMR (per 100000 births) , U5MR (per 1000 births), and HDI of certain West Asian countries, namely: Bahrain, India, Islamic Republic of Iran, Jordan, Kuwait, Pakistan, Qatar, Saudi Arabia, Syrian Arab Republic and the United Arabic Emirates from 1980 to 2010; data were extracted from the gap minder's site (16). The HDI is a summary measure that indicates the human development and level of quality of life. This measure calculated from the three sub-indicators that include: life expectancy, education attainment and GDP per capita (17). This measure can be calculated by a simple average of the three mentioned sub-indicators (18).

\section{Sample selection}

In this study, the west Asian countries with more complete information (the criteria for completing the information were based on data missing rate) about the variables under study were selected, as well as their similarity in development indices including: economic status, life expectancy and level of education.

\section{Data analysis}

The required data were analysed using SPSS 19 software, involving descriptive statistics and analytic methods such as Spearman correlation coefficient (due to nonparametric condition) to assess the correlation between the variables under study.

\section{Results}

The highest and the lowest rates of HDI in 2010 were found in the United Arabic Emirates (0.81) and Pakistan (o.49) respectively. The results showed that during 30 years HDI has had a growing trend in all countries. The highest HDI growth rate was found in the Islamic Republic of Iran at 0.2 (0.49 in 1985 and reaching 0.70 by 2010). The lowest rate of HDI for the same period was seen in Kuwait (0.10). The lowest MMR was found in the United Arabic Emirates (41.11 in 1980 and 7.14 in 2010). The highest MMR was found in Pakistan (746.09 in 1980 and falling to 335.45 in 2010). The results indicate that MMR had been decreasing during the research time period, and the greatest reduction was related to India.

According to the results, U5MR has had a declining trend during the research time period in all the countries. The lowest U5MR was related to Bahrain at 32.35 in 1980 and 8.36 in 2010, while the highest rates were found in India at 167.6 in 1980 and 91.8 in Pakistan in 2010. The highest rates of decrease were found in India and second highest in Islamic Republic of Iran.

The correlation between HDI and MMR, and correlation between HDI and U5MR were calculated as a total (Table 1) and by country (Table 2). There was a negative relationship between HDI and MMR $(r=-0.7$, $P<0.001$ ); thus, the increase of HDI would lead to the decrease of MMR. A similar relationship was found between HDI and U5MR $(r=-0.7, P<0.001)$ where the increase of HDI followed a significant decrease of U5MR. However, the correlation coefficient between MMR and U5MR was positive and significant $(\mathrm{r}=1.00, P<0.001)$. Therefore, MMR and U5MR were closely linked and as MMR increased, U5MR increased as well the trend of the three indices among the West Asian countries (by country and overall) as shown in figures 1 to 5 . According to these figures, the highest rate of HDI decrease was observed in Islamic Republic of Iran, and the greatest reduction of MMR was seen in India. Also, the highest decrease in U5MR was related to India as well.

\section{Discussion}

In this study we observed a downward trend in MMR from 1980 to 2010. The meta-analysis study showed that during a 28 -year period (from 1980 to 2008), MMR had decreased in 181 countries from 422 to 251 in 100 live births (1). In addition, another meta-analysis study indicated that a downward trend of MMR (2.5\%) had occurred around the world every year (19). The World Health Organization in collaboration with UNICEF showed that the rates of mortality reduction among women during a 20-year period (1990-2010) were 69\% in Eastern Asia, 64\% in Southern Asia, and 35\% in Central Asia (20). The reason for this downward trend might be the improvement of services and increase of public efficiency and awareness, although the contribution of HDI cannot be ignored, as

\begin{tabular}{|c|c|c|}
\hline variables & Correlation coefficient(r) & $P$ value \\
\hline HDI-MMR & -0.7 & $<0.001$ \\
\hline HDI-U5MR & -0.7 & $<0.001$ \\
\hline MMR-U5MR & 1.0 & $<0.001$ \\
\hline
\end{tabular}




\begin{tabular}{|c|c|c|c|}
\hline Country & Variables & Correlation coefficient(r) & Pvalue \\
\hline \multirow[t]{3}{*}{ Bahrain } & HDI-MMR & -0.99 & $<0.001$ \\
\hline & HDI-U5MR & -0.99 & $<0.001$ \\
\hline & MMR-U5MR & 0.98 & $<0.001$ \\
\hline \multirow[t]{3}{*}{ India } & HDI-MMR & -0.97 & $<0.001$ \\
\hline & HDI-U5MR & -0.99 & $<0.001$ \\
\hline & MMR-U5MR & 0.99 & $<0.001$ \\
\hline \multirow[t]{3}{*}{ Islamic Republic of Iran } & HDI-MMR & -0.9 & 0.01 \\
\hline & HDI-U5MR & -0.97 & 0.001 \\
\hline & MMR-U5MR & 0.97 & $<0.001$ \\
\hline \multirow[t]{3}{*}{ Jordan } & HDI-MMR & -0.97 & $<0.001$ \\
\hline & HDI-U5MR & -0.95 & $<0.001$ \\
\hline & MMR-U5MR & 0.97 & $<0.001$ \\
\hline \multirow[t]{3}{*}{ Kuwait } & HDI-MMR & -0.98 & $<0.001$ \\
\hline & HDI-U5MR & -0.97 & 0.001 \\
\hline & MMR-U5MR & 0.84 & 0.01 \\
\hline \multirow[t]{3}{*}{ Pakistan } & HDI-MMR & -0.90 & 0.005 \\
\hline & HDI-U5MR & -0.98 & $<0.001$ \\
\hline & MMR-U5MR & 0.95 & 0.001 \\
\hline \multirow[t]{3}{*}{ Qatar } & HDI-MMR & -0.99 & 0.01 \\
\hline & HDI-U5MR & -0.99 & 0.01 \\
\hline & MMR-U5MR & 0.99 & 0.01 \\
\hline \multirow[t]{3}{*}{ Saudi Arabia } & HDI-MMR & -0.98 & $<0.001$ \\
\hline & HDI-U5MR & -0.91 & 0.004 \\
\hline & MMR-U5MR & 0.96 & 0.001 \\
\hline \multirow[t]{3}{*}{ Syrian Arab Republic } & HDI-MMR & -0.99 & $<0.001$ \\
\hline & HDI-U5MR & -0.98 & $<0.001$ \\
\hline & MMR-U5MR & 0.99 & $<0.001$ \\
\hline \multirow[t]{3}{*}{ United Arab Emirates } & HDI-MMR & -0.99 & $<0.001$ \\
\hline & HDI-U5MR & -0.92 & 0.003 \\
\hline & MMR-U5MR & 0.90 & 0.005 \\
\hline
\end{tabular}

Figure 1 A comparison between the HDI of West Asian countries from 1980 to 2010

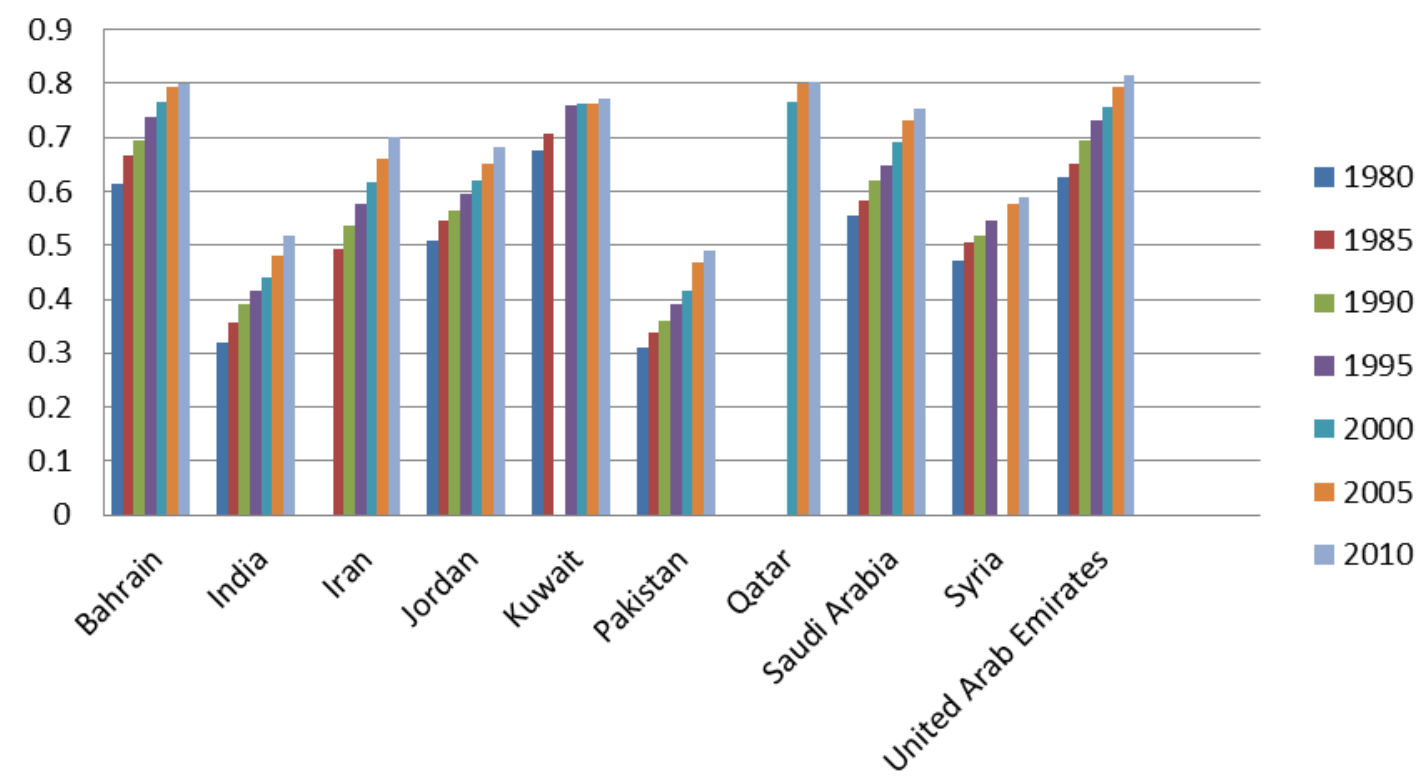


Figure 2 A comparison between the maternal mortality rates in West Asian countries from 1980 to 2010

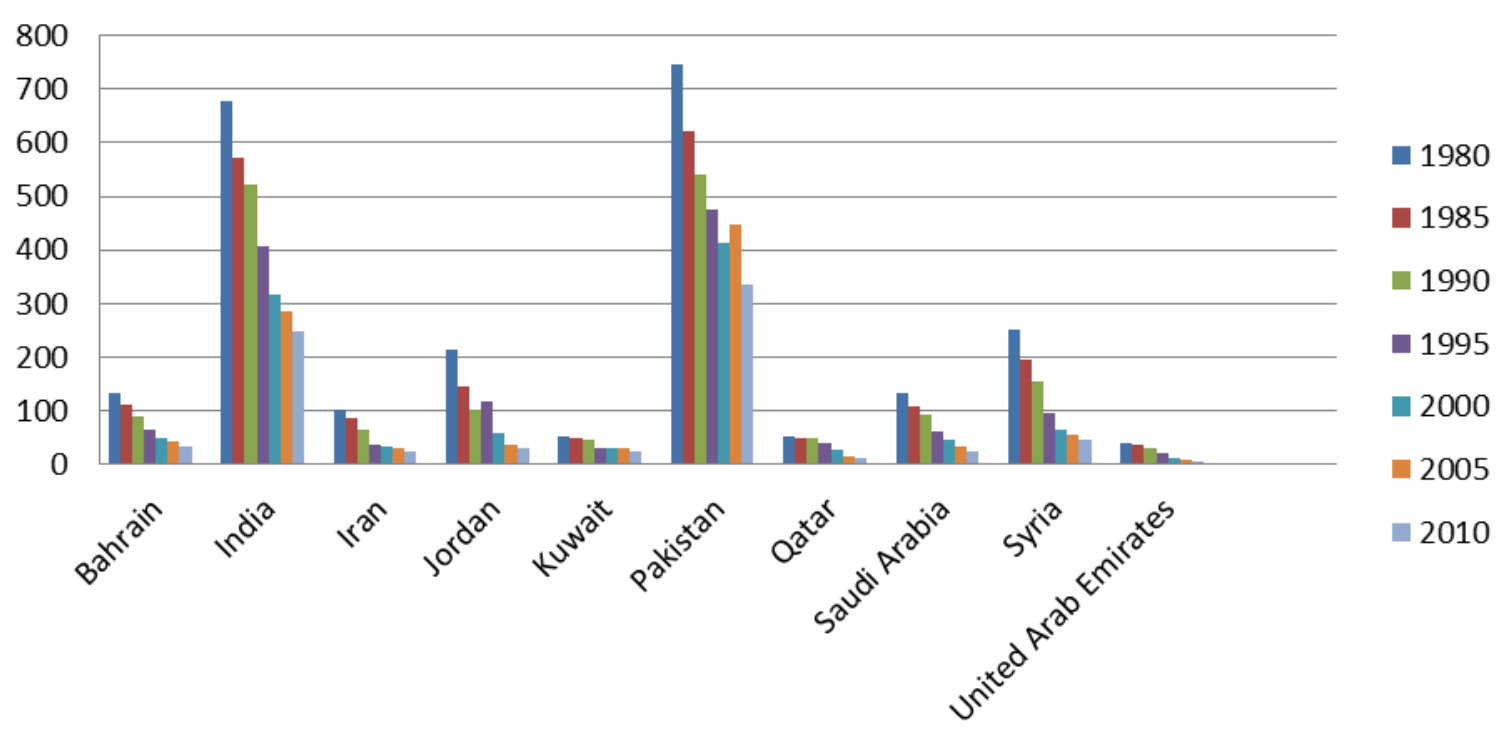

Figure 3 A comparison between the death rates of children under 5 years old in West Asian countries from 1980 to 2010

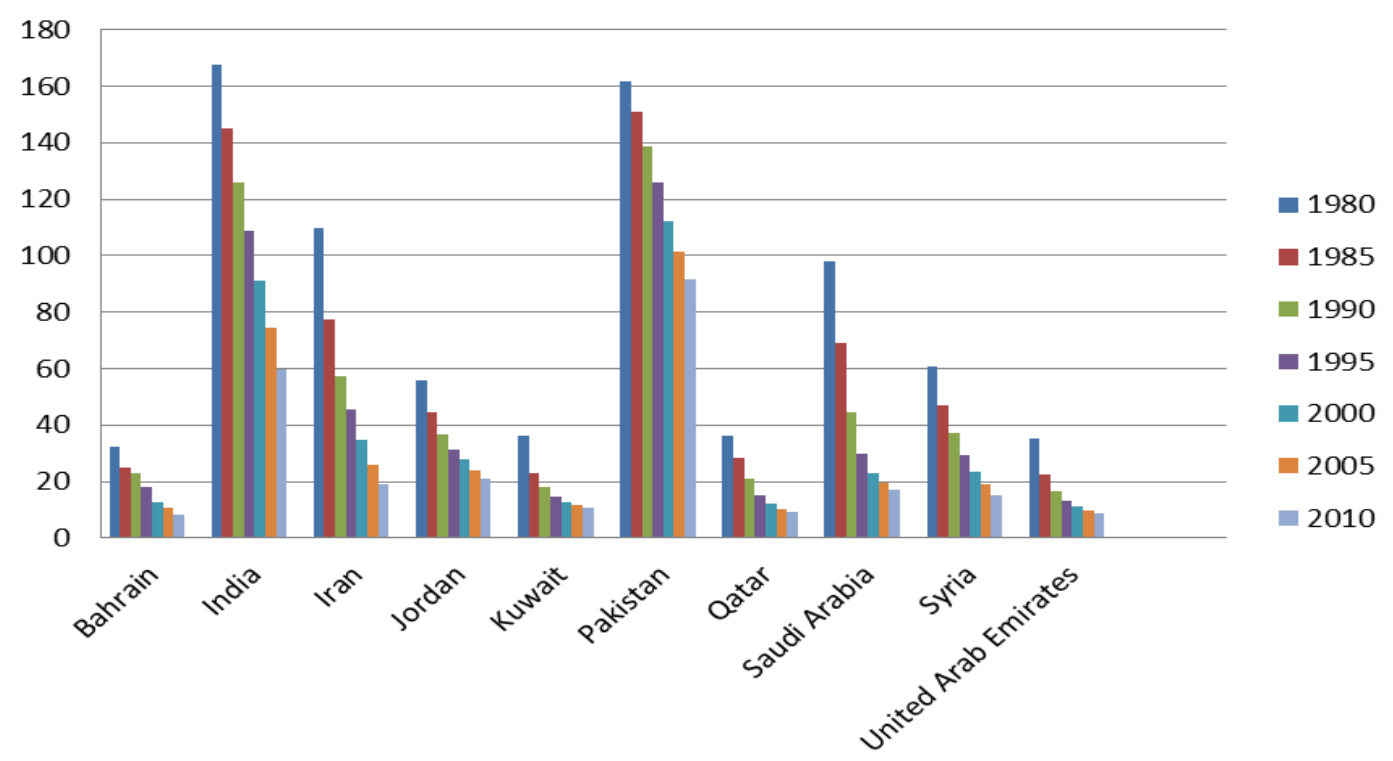

it seems that the increase of each HDI component (life expectancy, education level and income) might lead to the decrease of MMR. It must also be noted that despite the decline in female mortality in the world, only 16 countries have reached the Millennium Development Goals so far (1). Therefore, there are still some gaps in this regard, and identifying the reason might help solve this problem. Kassebaum stated in 2014 that most maternal deaths had occurred in higher-age groups and in intra-partum or postpartum periods (4). Hence, some interventions and programmes have to be applied for these high-risk groups in countries with high MMR. Also proper antenatal and obstetric care had a great role in decreasing MMR (1).

In the present study, U5MR has had a declining trend. In a French study it was seen that U5MR decreased from 1990 to 2011 in all low- and middle-income countries and this decrease was influenced by factors such as improvement of health care and economic status (21). A study carried out in 2000 showed that child mortality had had $17.5 \%$ decrease worldwide compared to the previous decade, but in some Southeast Asian countries where there are economic problems, the rate of child mortality is still high and as long as economic problems are not controlled, child mortality will remain high (22). A metaanalysis in 2008 showed that 8.795 million child deaths had occurred worldwide among $\mathrm{U}_{5} \mathrm{MR}(6)$. In our study the highest rate of decrease was related to India (167.6 to 59.9 in 100 live births from 1980-2010) and Iran (109.9 to 19.2 in 100 live births from 1980-2010). It seems that improving maternal education level, increasing age at marriage and birth gap between two births has an important role in decreasing $\mathrm{U}_{5} \mathrm{MR}$ in India (23). In the Islamic Republic of Iran the role of Iranian PHC system was significant in 
Figure 4 Trend of change in overall mean of HDI in all studied countries from 1980 to 2010

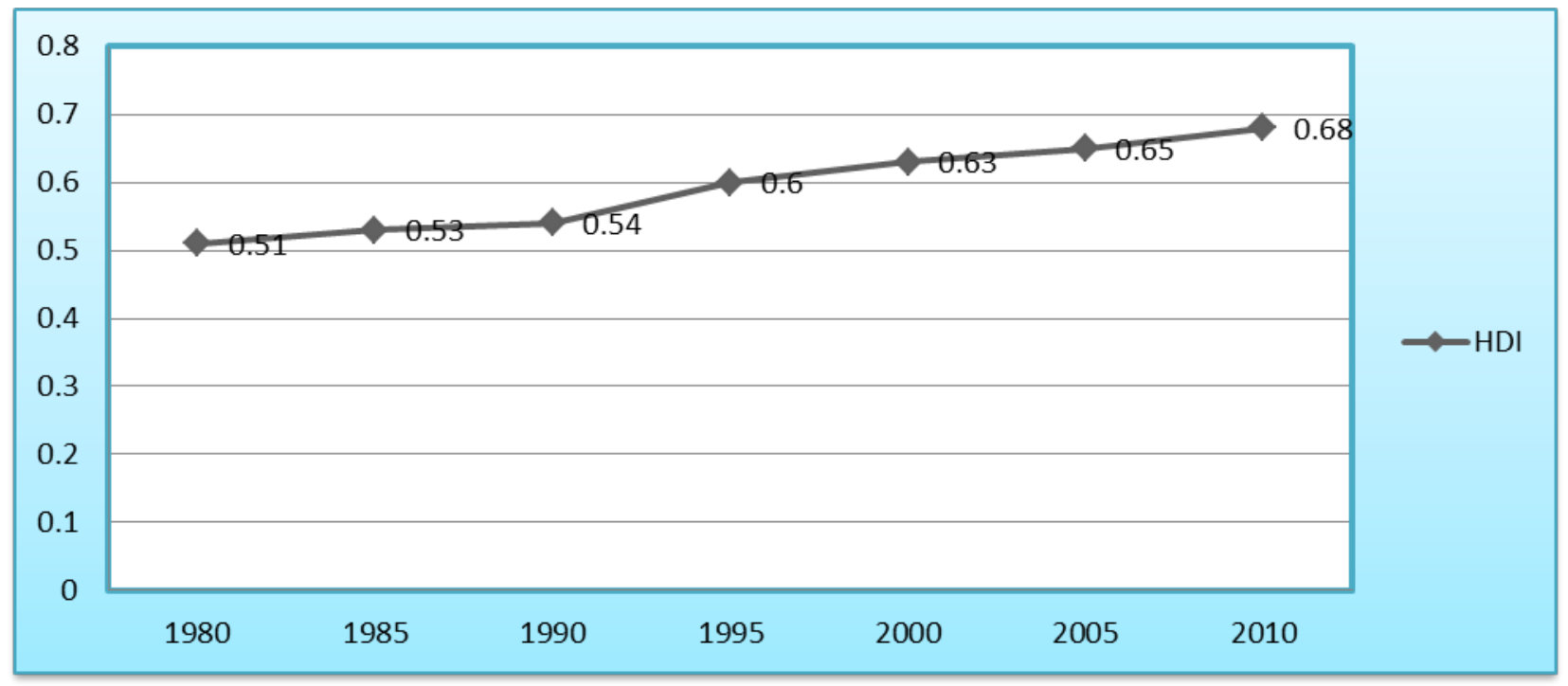

Figure 5 Trend of change in overall mean of MMR and U5MR in all studied countries from 1980 to 2010

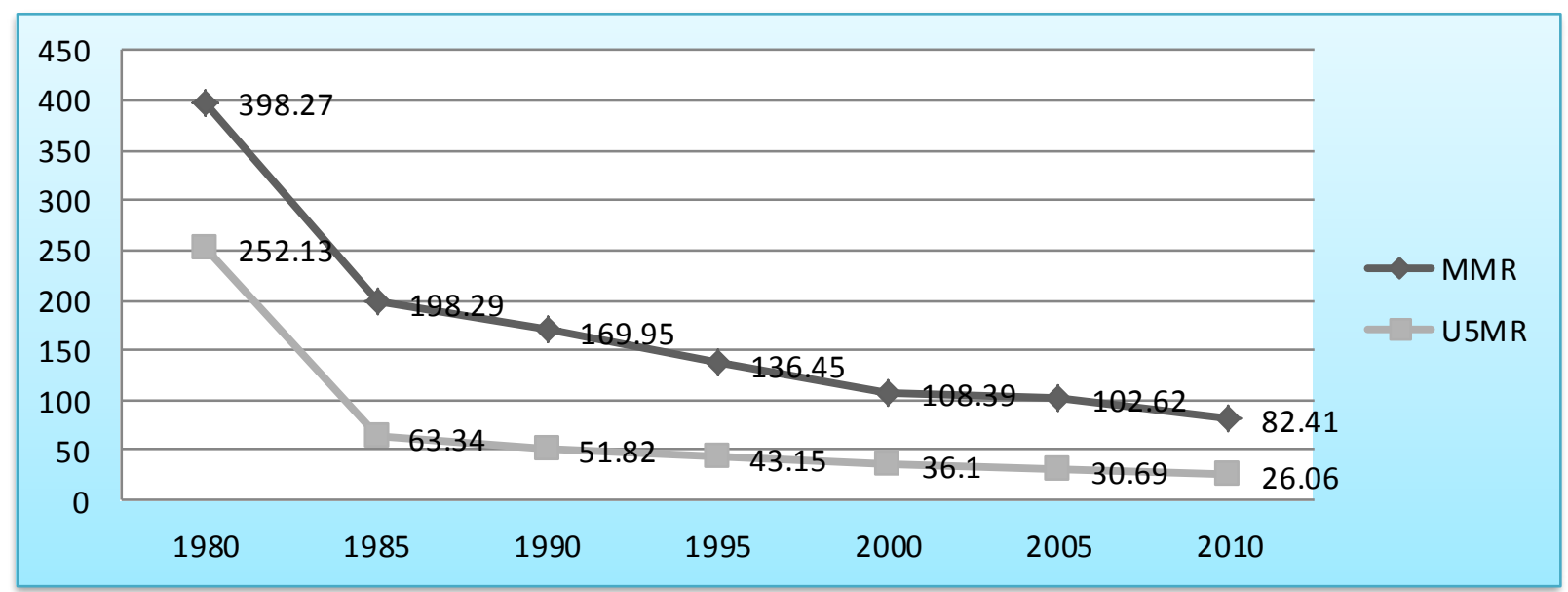

this decreasing trend (24). Other reasons for this declining trend are the following: improving community health status, earlier visit of patients, and improvement of diagnostic and therapeutic procedures (25). The current study results showed that there has been an increase in HDI in a 20-year period. Similarly, we can point to Asefzadeh s study that showed $7 \%$ increase in HDI during 1990-2008. Furthermore, the average life expectancy had increased during 18 years (19902008), rising from 65 to 69 years. During this period, the average income per capita was growing by $31 \%$. In addition, education level growth was 3\% during the same period (26). In another study, Jayachandran et al. showed $7.1 \%$ increase in life expectancy (27). In our study, the most improvement in HDI was related to the Islamic Republic of Iran due to improving government health expenditure; thus, improving life expectancy, economic growth, and education levels (28).
A significant correlation was seen between HDI and MMR. The data from 188 countries revealed that there was a negative correlation between HDI and its components, and MMR ( $\mathrm{r}=-0.807,95 \% \mathrm{CI}$ - $0.853,-0.747$, $\mathrm{P}=0.001)$. It was also found that most deaths of mothers could be observed in countries with low HDI and there was a statistically significant correlation between these two factors (29). Another study in 2012 confirmed these results (30).

In addition, there was a reverse relationship between HDI and U5MR. In a study conducted in 2015, the mean years of schooling showed a significant correlation with the decrease of mortality rates. In other words, as education level increased, health literacy of women rose as well. This led to better health, better care of their children and more attention of women to the health of their family, and thus reducing the mortality and morbidity (21). 


\section{Limitations}

Lack of updated information on studied countries, having incomplete data, and/or the lack of required information in many countries can be mentioned as the limitations of this study. Since it was a cross-sectional study, the causes of the increasing or reducing trend could not be determined. To reduce these limitations, a prospective study is suggested to be designed.

\section{Conclusion}

Generally, it was observed that U5MR and maternal mortality rate had a decreasing trend from 1980-2010. One of the most important causes of this decrease was the improvement of HDI; thus, by increasing educational levels, income per capita and life expectancy we might observe a substantial reduction in maternal and child mortality rates.

Funding: None.

Competing interests: None declared.

\section{Indice de développement humain, taux de mortalité maternelle et taux de mortalité des enfants de moins de cinq ans dans les pays d'Asie de l'Ouest et du Sud, 1980-2010 : étude écologique}

\section{Résumé}

Contexte : L'indice de développement humain (IDH), le taux de mortalité maternelle (TMM) et le taux de mortalité des moins de cinq ans constituent des éléments fondamentaux, notamment dans les pays à revenu faible et intermédiaire.

Objectifs : La présente étude avait pour objectif d'évaluer les changements survenus eu égard à l'indice de développement humain, au taux de mortalité maternelle et au taux de mortalité des moins de cinq ans entre 1980 et 2010 dans certains pays d'Asie occidentale, ainsi que la relation entre ces différents indicateurs.

Méthodes : Dans cette étude écologique, les informations liées à l'indice de développement humain, et au taux de mortalité maternelle et à celui des moins de cinq ans dans les pays étudiés entre 1980 et 2010 ont été extraites à partir du site Web Gapminder, puis analysées à l'aide de méthodes descriptive et analytique, notamment de la corrélation de Spearman.

Résultats: En 2010, les taux les plus bas et les plus élevés pour l'indice de développement humain et la mortalité maternelle ont été observés aux Émirats arabes unis et au Pakistan (IDH : 0,49 et 0,81; et TMM: 7,14 et 335,45 respectivement). L'indice de développement humain connaît une augmentation dans tous les pays étudiés, avec l'augmentation la plus notable en République islamique d'Iran $(0,21)$. Les taux de mortalité maternelle et des enfants de moins de cinq ans ont connu une baisse au fil des années, la plus importante ayant été notée en Inde. En 2010, Bahreïn affichait le taux de mortalité infantile le plus bas $(8,3)$ et le Pakistan le plus élevé (91.8). Néanmoins, il existait une relation négative entre l'indice de développement humain et le taux de mortalité maternelle $(r=-0,7, p<0,001)$.

Conclusions: L'indice de développement humain a augmenté entre 1980 et 2010, tandis que le taux de mortalité maternelle et celui des enfants de moins de cinq ans ont diminué. À ce titre, l'amélioration de l'Indice de développement humain pourrait avoir une certaine influence sur la baisse des taux de mortalité maternelle et des moins de cinq ans, en particulier dans les pays à revenu faible ou intermédiaire.

$$
\begin{aligned}
& \text { مؤشر التنمية البشرية، ومعدل وفيات الأمهات، ومعدل وفيات الأطفال دون الخامسة في بلدان غرب وجنوب آسيا، }
\end{aligned}
$$

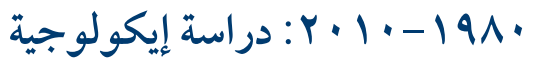

$$
\begin{aligned}
& \text { يو سف على محمدى، فرزاد خدامر ادى، مليحه خرمداد، محمد شهباز، فيروز اسماعيل زاده } \\
& \text { الخالاصة } \\
& \text { الخلفية: يُعَُّّ مؤشر التنمية البشرية، ومعدل وفيات الأمهات، ومعدل وفيات الأطفال دون الخامسة من القضايا الأساسية، لا سيّما في البلدان } \\
& \text { منخفضة ومتوسطة الدخل. }
\end{aligned}
$$

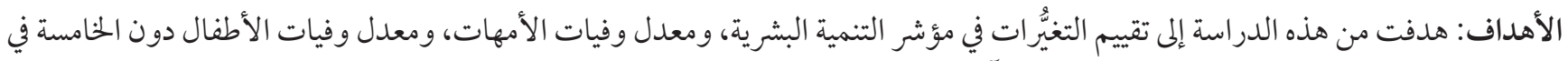

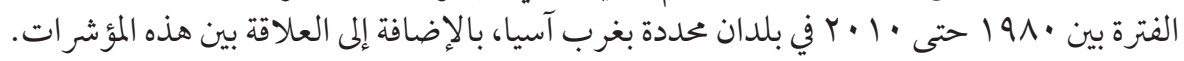

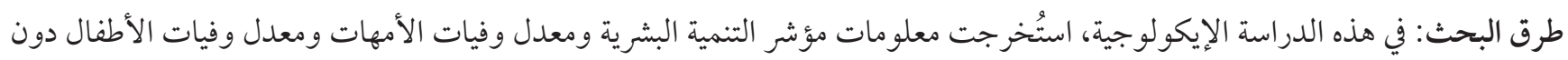

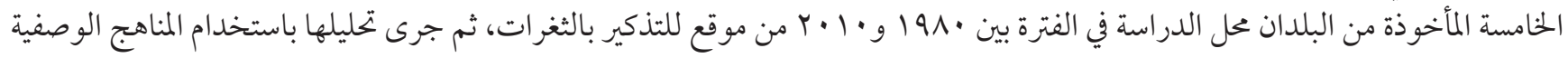

$$
\begin{aligned}
& \text { و التحليلية، بما في ذلك معامل ارتباط سبيرمان. }
\end{aligned}
$$




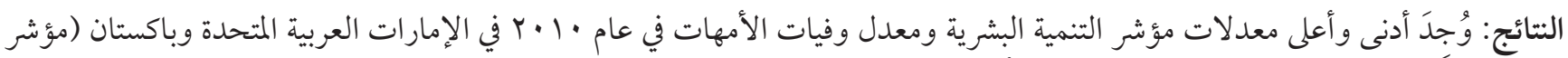

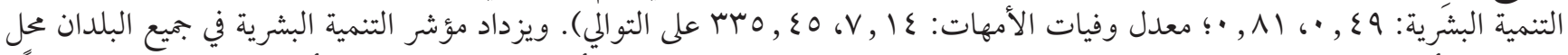

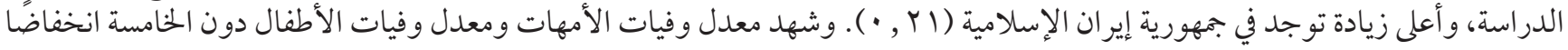

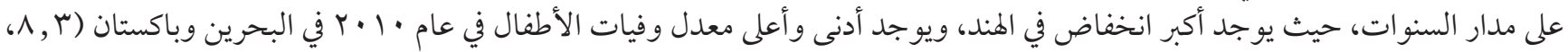

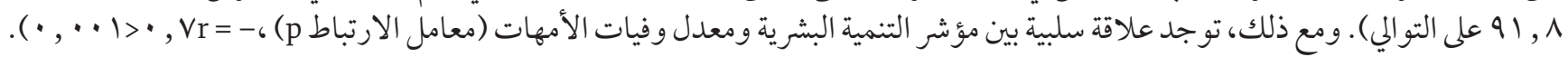

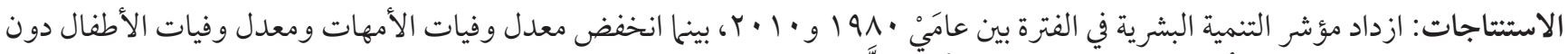

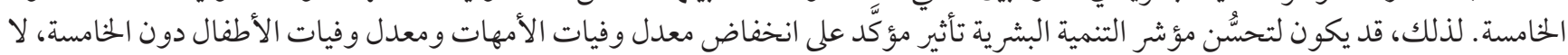

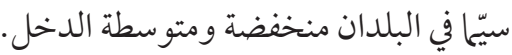

\section{References}

1. Hogan MC, Foreman KJ, Naghavi M, Ahn SY, Wang M, Makela SM, et al. Maternal mortality for 181 countries, 1980-2008: a systematic analysis of progress towards Millennium Development Goal 5. Lancet. 2010;375(9726):1609-23. http://dx.doi.org/10.1016/ So140-6736(10)60518-1

2. Bhatia JC. Levels and causes of maternal mortality in southern India. Stud Fam Plann. 1993;24(5):310-8. http://dx.doi. org/10.2307/2939224

3. United Nations. The Sustainable Development Goals Report 2016. New York: United Nations; 2016.

4. Kassebaum NJ, Bertozzi-Villa A, Coggeshall MS, Shackelford KA, Steiner C, Heuton KR, et al. Global, regional, and national levels and causes of maternal mortality during 1990-2013: a systematic analysis for the Global Burden of Disease Study 2013. Lancet. 2014;384(9947):980-1004. http://dx.doi.org/10.1016/S0140-6736(14)60696-6

5. Bartlett L, LeFevre A, Zimmerman L, Saeedzai SA, Turkmani S, Zabih W, et al. Progress and inequities in maternal mortality in Afghanistan (RAMOS-II): a retrospective observational study. Lancet Glob Health. 2017;5(5):e545-55. http://dx.doi.org/10.1016/ S2214-109X(17)30139-0

6. Black RE, Cousens S, Johnson HL, Lawn JE, Rudan I, Bassani DG, et al. Global, regional, and national causes of child mortality in 2008: a systematic analysis. Lancet. 2010;375(9730):1969-87. http://dx.doi.org/10.1016/So140-6736(10)60549-1

7. Singh GK, Yu SM. Infant mortality in the United States: trends, differentials, and projections, 1950 through 2010. Am J Public Health. 1995;85(7):957-64. http://dx.doi.org/10.2105/AJPH.85.7.957

8. United Nations. The Sustainable Development Goals: United Nations; 2016 (http://www.un.org/sustainabledevelopment/health/).

9. Jiménez J, Romero MI. Reducing infant mortality in Chile: success in two phases. Health Aff. 2007;26(2):458-65. http://dx.doi. org/10.1377/hlthaff.26.2.458

10. Neumayer E. The human development index and sustainability-a constructive proposal. Ecol Econ. 2001;39(1):101-14. http:// dx.doi.org/10.1016/S0921-8009(01)00201-4

11. Despotis D. A reassessment of the human development index via data envelopment analysis. J Oper Res Soc. 2005;56(8):969-80. http://dx.doi.org/10.1057/palgrave.jors.2601927

12. Santra S. Is Human Development Index (HDI) a reflector of quality of air? A comparative study on developed and developing countries. IJSRP. 2014;4(2):2250-3153.

13. Giebel S, Labopin M, Ehninger G, Beelen D, Blaise D, Ganser A, et al. Association of Human Development Index with rates and outcomes of hematopoietic stem cell transplantation for patients with acute leukemia. Blood. 2010;116(1):122-8. http://dx.doi. org/10.1182/blood-2010-01-266478

14. Cahill MB. Is the human development index redundant? East Econ J. 2005;31(1):1-5.

15. Sagar AD, Najam A. The human development index: a critical review. Ecol Econ. 1998;25(3):249-64. http://dx.doi.org/10.1016/ So921-8009(97)00168-7

16. Gap Minder (https://www.gapminder.org/data/).

17. Bray F, Jemal A, Grey N, Ferlay J, Forman D. Global cancer transitions according to the Human Development Index (2008-2030): a population-based study. Lancet Oncol. 2012;13(8):790-801. http://dx.doi.org/10.1016/S1470-2045(12)70211-5

18. Wolff H, Chong H, Auffhammer M. Classification, detection and consequences of data error: evidence from the human development index. Econ J. 2011;121(553):843-70. http://dx.doi.org/10.1111/j.1468-0297.2010.02408.x

19. Hill K, Thomas K, AbouZahr C, Walker N, Say L, Inoue M, et al. Estimates of maternal mortality worldwide between 1990 and 2005: an assessment of available data. Lancet. 2007;370(9595):1311-9. http://dx.doi.org/10.1016/So140-6736(07)61572-4

20. UNICEF. Trends in maternal mortality: 1990-2010. New York: UNICEF; 2012.

21. French D. Did the Millennium Development Goals change trends in child mortality? Health Econ. 2016;25(10):1312-25. http:// dx.doi.org/10.1002/hec.3218

22. Ahmad OB, Lopez AD, Inoue M. The decline in child mortality: a reappraisal. Bull World Health Organ. 2000;78:1175-91. 
23. Sahu D, Nair S, Singh L, Gulati B, Pandey A. Levels, trends \& predictors of infant \& child mortality among Scheduled Tribes in rural India. Indian J Med Res. 2015;141(5):709.

24. Asadi-Lari M, Sayyari A, Akbari M, Gray D. Public health improvement in Iran-lessons from the last 20 years. Public Health. 2004;118(6):395-402. http://dx.doi.org/10.1016/j.puhe.2004.05.011

25. Rahbar M, Ahmadi M, Lornejad H, Habibelahi A, Sanaei-Shoar T, Mesdeaghinia A. Mortality causes in children 1-59 months in Iran. Iran J Public Health. 2013;42(1):93.

26. Alijanzadeh M, Asefzade S, Moosaniyae Zare SA. Correlation between Human Development Index and maternal mortality rate worldwide. Biotech Health Sci. 2016 February; 3(1):e35330. http://dx.doi.org/10.17795/bhs-35330

27. Jayachandran S, Lleras-Muney A. Life expectancy and human capital investments: Evidence from maternal mortality declines. National Bureau of Economic Research, 2008.

28. Razmi SMJ, Abbasian E, Mohammadi S. Investigating the Effect of Government Health Expenditure on HDI in Iran. Journal of Knowledge Management, Economics and Information Technology. 2012;2.

29. Almasi-Hashiani A, Sepidarkish M, Vesali S. Omani Samani R. The Correlation of Human Development Index on Fertility and Mortality Rate: a Global Ecological Study. Int J Pediatr. 2016;4(12):4071-80.

30. UNFPA U. WHO BW. Trends. Maternal Mortality: 1990-2010. Geneva: WHO Google Scholar; 2012. 